\title{
A CRITICAL REVIEW AND ASSESSMENT OF THE SOCIOLOGY OF LAW*
}

\author{
Arlene Sheskin \\ Central Michigan University
}

Literature in the sociology of law has been increasing but, as yet, this growth has been accompanied by few theoretical assessments of the field or the state of knowledge which has been produced. ${ }^{1}$ This paper will be concerned with such an assessment.

In particular, I am interested in delineating the theoretical underpinnings of the sociology of law as exhibited in the works of sociologists and sociological jurisprudents. From such a review I will demonstrate the linkage between particular theoretical assumptions about the world and the laws place in it, and present day research. Finally, in commenting upon one theme in current research, I hope to indicate the extent to which its limitations are a function of a particular world view and to suggest a different set of theoretical assumptions which would lead to markedly different research endeavors. In sum, I will be concerned with the relationship between theory and research and the limitations imposed by particular theories in the sociology of law today.

\section{THE IMPORTANCE OF THEORETICAL ASSUMPTIONS}

An acceptance of the necessity of law is a primary characteristic of theories in the sociology of law. Theorists who have written in this area have tended to perceive the law as a necessary and positive ingredient in the maintenance of social order and the attainment of progress and, consequently, have taken the present system of law for granted.

Where deficiencies or inequities in the law are noted, they have been deemed amenable to scientific knowledge and expertise. Researchers in law have invoked scientific procedures as the basis

\footnotetext{
*I would like to thank Neal Shover for many helpful comments and criticisms.
} 
upon which remedies should rest. They have insisted that theories be tested-that important concepts be operationalized and submitted to the "strict" canons of empirical verification before changes in the law are made. However, despite this emphasis on research, theories and research on law have been unable to account for hostility directed against law or for the failure of scientific remedies to be instituted or to work as planned once they are accepted.

The reasons for such failure may be seen in the assumptions of the theories as well as in the beliefs of both theorists and researchers that scientific social engineering is dependent only upon the operationalization of concepts and the accumlation of knowledge, and that these can exist apart from, or remain uninfluenced by, assumptions about the world.

It is necessary to recognize that theories are not objective pronouncements generated by a disinterested, objective assessment of the world. Instead, theories are generated by tensions in the theorist's personal world which he feels must be assuaged; intuitive hunches, which are rarely explicated and even less often subject to verification, provide the basis upon which theories are constructed (Gouldner, 1970; Phillips, 1974).

Of course, while theory may be generated by personal experiences, such experiences as well as interpretations of them, are not merely the result of individual idiosyncracies. For example, members of particular strata tend to have in common their socialization patterns as well as life experiences. Such commonalities are further augmented by membership in a professional group and belief in a professional ideology (Mills, 1941; Snodgrass, 1972).

The theorists to be discussed had much in common. They were reared in professional, economically comfortable homes, and received university and legal training at a time when few were so educated. One can suppose that the world which they experienced was generally placid, orderly and personally satisfying. ${ }^{2}$ As such, it is not surprising to find, among sociologists and sociological jurisprudents, common assumptions about the law which reflect the conditions of their lives. The question then, in analyzing their theories, is not how true they are but rather what the theory reveals about a particular world view and the extent to which the theorist's assumptions precluded alternative explanatory schemes. Thus, in the following analysis, we will be interested in the ways in which the assumptions which legal theorists held about the world may have precluded more accurate explanations of the workings of the world.

\section{SOCIOLOGICAL JURISPRUDENCE}

Two of the first legal theorists to advance a sociological approach to the study of law were Eugen Ehrlich and Roscoe Pound. The origins of the field have been traced to their work (e.g., Schur, 1968), and their assumptions continue to be reflected in current research and writing in this area.

As will be seen, the characteristics which mark their approach include an assumption of pluralism, a reification of the law, the postulation of a necessary congruence between the law and the attitudes and values of the corresponding populace, and a cautious approach to instituting legal change. This caution, it should be noted, was predicated on their belief that scientific research was eminently suited and needed to direct such change.

\section{EHRLICH}

Eugen Ehrlich is generally recognized as the founder of sociological jurisprudence. Responding to the shortcomings of analytical and historical jurisprudence, he stressed the necessity for studies of the law to be situated within a societal context. This directive was premised upon Ehrlich's postulation of a living law-"the law which dominated life itself"-which had existed in social associations prior to the development of state law and which, in fact, served as its basis. As he saw it:

The human relations upon which a presentation of the law must be based, are independent of the legal propositions.... The various legal propositions as such ...have no information to convey. If 
there is a unifying regularity in the phenomena of legal life, to discover and make a presentation of which is the function of sociology, it can be found only in the fact that legal life is conditioned upon the social and economic constitution (Ehrlich, 1936:475-477).

But, Ehrlich recognized that the relationship between the living law and the statutes was not always easily seen or understood. Thus, the sociology of law was to be concerned with the manner in which the "ends may be attained that men are endeavoring to attain through law" (Ehrlich, 1936:202).

Asserting that the sociology of law should trace the relationship between the positive and the living law, Ehrlich laid down a method by which to do so. He stated:

There is no other means (to facilitate such understanding) but to open one's eyes, to inform oneself by observing life attentively, to ask people and to note down their replies (Ehrlich, 1936:498).

While comments upon such methodological directives are not in order now, it should be noted that between opening one's eyes and understanding comes a long process of interpretation and that this process is mediated, as least in part, by one's position in the social hierarchy. The faith which Ehrlich and those who have followed him have placed in science and careful measurement is based upon faith and this cannot be forgotten if one is to understand the limitations of Ehrlich's methodological directives as well as the limitations of the studies which have attended them. Thus, in analyzing assumptions we are not limited only to those regarding the nature of law and society. We are also interested in showing the ways in which belief in the scientific study of the law as the basis for, and initiator of, legal change has been misguided.

Ehrlich's view of the state in the creation of law is essentially non-coercive; it is bolstered by his assumption that the actions of the state are predicated upon the needs and will of the people and that the efficacy of the law is dependent upon its correspondence
Sociology of Law

with the majorities "inner impulses." Thus, Ehrlich is not troubled by the state's increasing role in the administration and creation of law because the state is seen as merely reflecting the proclivities of its citizenry.

While Ehrlich touches on differential participation in the development of law his assumptions about the necessary correspondence between law and general interest keep him from pursuing the implications of such participation. In his discussion of legal history he states:

Those persons who master the learning of decisions achieve a great influence in the development of the law; they become jurists who, occasionally as judges but more often as writers of opinions and counselors determine the course of decisions (Ehrlich, 1922:134).

Only in a world where power is viewed benignly and is not associated with force or coercion can one rest content with such a statement. One who eschews the assumption of general interests which are naturally or neutrally determined and then reflected in law is prompted to inquire which members of society master the learning of decisions, whether those who achieve great influence are members of a particular strata, and of course, the paramount question, the degree and extent of their influence. As we have seen, the fact that these questions remain unanswered tells us more about Ehrlich's assumptions about the world than it does about the importance of such concerns.

\section{POUND}

While Ehrlich delineated the foundations of what was to become sociological jurisprudence Pound was its major architect and through his voluminous writings did the most to establish its legitimacy as a school of legal philosophy. It should be noted too that, while Pound and Ehrlich shared fundamental assumptions about the nature of law, Pound's assumptions were somewhat more complex in that he, at least, recognized the competing interests with which the law deals. 
Mid-American Review of Sociology

Pound conceived the law to be a specialized agent of social control $^{3}$-in short, the pressure brought to bear upon each man in order to constrain him to do his part in upholding civilized society and to deter him from anti-social conduct-conduct at variance with the social order (Pound, 1942:210). Here, we see evidence of both the reification of society and the law. Society is portrayed as having an independent existence with needs of its own quite apart from, or even at variance with, those of some societal members. The continuance of society is then sanctified and the law is seen as having a special mission in contributing to its continuance. While the potential of law to exert pressure is noted in Pound's definition of its role, there is little question that any pressure exerted is perceived as legitimate.

Pound did not, however, profess complete affinity between the law and all interests in society. He was cognizant of the complexity of societies and recognized the diverse interests by which they were characterized. But his theoretical reconciliation of diversity was accomplished apart from any considerations of differential power. Thus, Pound asserts:

The law is an attempt to satisfy, to reconcile, to harmonize. To adjust these overlapping and often conflicting claims and demands, either through securing them directly and immediately or through compromises of individual interests so as to give effect to the greatest total of interests or to the interests that weigh most in our civilization, with the least sacrifice to the scheme of interests as a whole (Pound, 1943:39).

Here we see the law as a reified, neutral, mediative agent in a pluralistic world. From this perspective, the full satisfaction of interests is not so important as the fact that the effort towards satisfaction is made. This effort is the salient feature of legal institutions in Pound's work. That certain interests are sacrificed for the sake of others is taken for granted as a necessary condition of social order. That some interests may be more fully satisfied than others posed no problems for Pound.
Sociology of Law

Finally, it was his interest in social engineering which led Pound to urge a partnership between sociology and law. Sociology, with its scientific methods was to delineate the social interests of society. With the completion of this task jurists presumedly were to have the foundation upon which to construct a legal scheme which would insure that the "maximum satisfaction of socially worthwhile purposes might be accomplished" (Pound, 1912:491).

It must be stressed that while Pound emphasized the role of law in social engineering, that engineering was to take place within well-defined parameters. The desirability of particular forms of social progress-(e.g., capitalism, industrialism)-was not at issue. Neither was law to be used to alter the course of such progress. Rather, the law was seen as a dependent factor in social life whose job was the reflection and maintenance of the society's crucial values.

In maintaining that the law should be the mediator of competing interests, Pound (1916) worried about attempts to have the law enforce or reflect a morality which was not yet commonly agreed upon. In this, we see again, his belief in law as a dependent factor in social life. His major concern was that when moral demands which did not reflect the consensus of the community were placed upon the law, the efficacy of the law's control would be diminished.

In postulating agreement between attitudes and the efficacy of the law's control, and in worrying lest the law be called upon for tasks beyond its competence, the limitations of Pound's thesis are apparent. Most obviously, he fails to consider instances where social control is exerted effectively without a corresponding belief, on the part of the majority, in the morality of law. The limits of effective legal action may have less to do with the limitations inherent in law as an institution than they do, for example, in the inclination of law enforcers or legislators not to enforce the law in its newly prescribed form. The many instances where law has been used to affect changes which were at odds with the populace are conveniently overlooked (see Parks, 1970; Katz, 1968; Chambliss, 1964; Silver, 1967). 


\section{SOCIOLOGICAL APPROACHES}

Lest one think that assumptions of the law's legitimacy are limited to legal theorists, who might be expected to be biased in their evaluation of it, we need only turn to sociologists for evidence that such is not the case. In delimiting the sociology of law, sociologists have established parameters similar to those seen among sociological jurisprudents.

The sharing of assumptions and errors is best evidenced in the work of Timascheff who was among the first to attempt the delimitation of the sociology of law. For Timascheff, "law was a cultural force whose function was the imposition of norms of conduct ... on the individual will" (Timascheff, 1937:225). Thus, Timascheff echoes Pound in his emphasis on law as a form of social control and he is similar to him as well in reifying the law, assuming its legitimacy, and divorcing it from any consideration of power or oppression.

Time has not negated the potency of such assumptions among sociologists; similar theoretical views continue to be promulgated. Selznick (1959), for example, tells us that:

There is no need ... to insist that legal rules be tested by practical effects... (because) little will be gained from further demonstration that law serves social interests and that these interests in turn reflect the changing structure of society (Selznick, 1959:117).

$\mathrm{He}$, of course, is not alone in his views. Sociological studies of law continue to be marked by an acceptance of the present system of law as well as by a consensus as to its necessity for social order (see Quinney, 1974). Thus, attention is paid to ways in which the present system can be improved or made more efficient. Again, we see the assumption that reform awaits scientific knowledge and expertise. $^{4}$
Sociology of Law

\section{AN ASSESSMENT}

The greatest failing of traditional sociological jurisprudence is that by assuming a particular reality of law, further inquiry into the nature and role of law is precluded. The assumptions displayed are particularly striking in that there is so little empirical evidence to support them. ${ }^{5}$

An immediate problem is presented by the assumption that law which evokes conformity is law which corresponds to general or social interests. This equation of conformity and agreement is shortsighted at best. While Pound and Ehrlich and a number of sociologists may be indifferent to the existence or importance of power in the social world, societal members (especially those against whom it is directed) are not. As Gerth and Mills have noted, the motives for conformity to law range from calculations and fear of possible sanctions to an absolute belief in the justice or ethical qualities of the law (Gerth and Mills, 1953:262). The latter motivation cannot merely be assumed to be the true one.

The consensus upon which law is supposedly based is postulated in an a priori manner and as such appears more problematic than real. If no consensus is found, or when the one that is discovered is less broadly based than one would infer is necessary to represent the social interests of the community, then the assumption that law cannot exist or be effective unless it corresponds to general interests becomes less tenable.

The reification of the law poses particular problems. We learn, for example, that the law reflects interests or that it is a neutral mediative agent. Little effort is made to explicate what the law is or who takes part in its construction or administration. Thus, evidence with regard to the shared social class of legal actors is seen as an interesting coincidence rather than as a perhaps telling commentary about the system.

Without clarification, we are left to conclude that the law has a life of its own. But, since magical forces or mysticism are not generally accepted as explanations of phenomena of the social world, we must be interested in a delineation of the forces or interests which are responsible for the workings of the system. 
Thus, in concluding our assessment of the reality of law advanced by sociologists and sociological jurisprudents, we must note the essentially conservative nature of their thought. Delineating the elements of such thought, Mannheim (1971) has noted its adherence to concrete situations, its concern with the immediate without an examination of the social structure in which it exists, its tendency to see the present as the finished and inevitable product of a long process of growth and concommitantly to guard what is, rather than imagine what might be.

As should be clear from our discussion, theories of law exhibit such characteristics. Thus, Ehrlich's insistence on the living law as the basis upon which positive law must rest and Pound's fear-expressed in the "Limits of Effective Legal Action"-of disturbing what already exists are all indicative of conservative thought. Finally, in taking the present system of law for granted and in cautioning against change all the theorists we have discussed display the prime tenets of conservative thought in their work.

\section{ALTERNATIVES}

Currently, there is a growing body of theorists and researchers who have divorced themselves from the predominant assumptions of the sociology of law. ${ }^{6}$ As yet, we do not know enough about these individuals to speculate whether differences in social background might account for the new ways in which they approach the study of law. However, we do know that their work has developed in a climate where official definitions of reality have come under close scrutiny, leading them to engage in a critical analysis of law and society.

One does not have to fully embrace Marx's notions of law to recognize that the theories of law we have discussed are inadequate and incomplete; nor does cne have to be a Marxist to engage in a critical analysis of law. Instead, one needs only to be cognizant of the importance of power, economics and politics in the development of law. As we shall see, when such considerations guide empirical research, traditional assumptions about law become less and less tenable.
Sociologists and sociological jurisprudents have tended to speak of "the law" as a whole. Because they assumed that law mediated between and then reflected interests and that all interested parties were engaged in the expression of such interests, they ignored the historical development of particular laws. In addition to ignoring its history, there has been a tendency as well to divorce the "law" from its everyday workings or from its enforcement. As such, the "law" remained pure even when law in everyday life seemed to act very differently.

When law is approached historically and its study is guided by considerations of power and economics we find that the pluralistic assumptions about the nature of its development are no longer appropriate (Domhoff, 1969; Stern, 1970). We find instead that all affected groups do not participate in determining the contents of particular laws (Akers, 1975; Roby, 1969; Kunitz, 1974), and that the development of particular laws as well as features of the legal system are closely tied to the needs of the economically dominant classes (Chambliss, 1964; Weinstein, 1968; Josephson, 1934; Quinney, 1974; Barak, 1975; Platt, 1974; Serber, 1975).

It appears as well that even those laws which have been assumed to reflect the general interests of societal members at the expense of dominant classes have had, upon closer inspection, different origins than are commonly assumed. They also appear to work very differently from what one would expect if the safeguarding of general interests were their intent. Thus, Kolko (1963) shows that the federal regulation of business, which is commonly thought to be an example of the law protecting and reflecting the general interests of the citizenry, actually served the economic interests of those who were being regulated and that such legislation was supported by them. Similarly, analysis of work compensation laws indicates that they were enacted only after employers recognized that their interests would be served by such legislation (Friedman \& Ladinsky, 1967).

Even when laws are enacted at the protest of dominant classes this does not necessarily mean that general interests have prevailed. As Ridgeway has noted with regard to air pollution 
legislation, there is a large gap between the enactment of statutes and their enforcement (cited in Gordon, 1973). Thus, the presence of a law may assuage tensions even though it is not enforced. In cases such as these the ideological aspects of law are most apparent.

Finally, the issue of crime seriousness appears very different when it is addressed critically. For example, we have noted that violent crimes are rated most serious. In considering this finding Gordon (1973) wonders why it is that some crimes-particularly those associated with the poor-tend to be violent while others (e.g., white collar crimes) are not. He notes that the police and courts pay careful attention to only a few crimes and that, as a result, those who run the highest risks of arrest and conviction have to rely on the threat or commission of violence in order to protect themselves. Thus, he argues that if white collar criminals were pursued and prosecuted we could expect them to resort to similar types of behavior. As such, he concludes that "many of the differences in the degree of violence among different kinds of crime do not cause the selectivity of public concern about those crimes but are in fact caused by that selectivity" (emphasis in the original). As we have seen, explanations of this type, are not even considered when the tenets of sociological jurisprudence are assumed to be true.

\section{CONCLUSION}

It has often been observed that ways of seeing are also ways of not seeing. The preceding discussion has indicated what traditional theories and research in the sociology of law have failed to see as a result of their taken-for-granted assumptions about the law.

We have seen that when such assumptions are eschewed the law appears very differently. In short, critical analyses of law have shown that law does not naturally or neutrally reflect the interests of the populace-that it is more likely to be determined by and reflect the interests of the economically dominant classes. As such, legal change is not dependent upon scientific knowledge and expertise. Instead, we have noted the ways in which such knowledge serves to legitimate the existing order.

Finally, we must again emphasize the importance of situating studies of law within an historical and economic context if we are to understand the nature of law as well as its relationship to other institutions in society.

\section{NOTES}

1. For other critiques of the sociology of law see D. Black, "The Boundaries of Legal Sociology," Yale Law Journal 81(May 1972) pp. 1086-1110 and E. Currie, "The Sociology of Law: The Unasked Questions," Yale Law Journal 81(November 1972), pp. 134-147.

2. For more detailed information about Pound's background see $S$. Simpson, "Roscoe Pound and Interpretations of Modern Legal Philosophy," New York University Law Quarterly 23(1948) pp. 393-411 and L. Cassidy, "Dean Pound: The Scope of His Life and Work," New York University Law Quarterly 7(1930) pp. 897-940. For information about Ehrlich see Pound's introduction to Eugen Ehrlich, The Fundamental Principles of the Sociology of Law, Cambridge: Harvard University Press, 1913.

3. Pound's concern with social control can be traced to his association with two sociologists-Small and Ross. For an examination of their influence on his work see G. Geis, "Sociology and Sociological Jurisprudence: Admixture of Law and Lore," Kentucky Law Journal 52(Winter 1964), pp. 267-293. For a consideration of the conservative and procapitalist nature of their theories see D. Smith, "Sociology and the Rise of the Corporate State," Science and Society 29(Fall 1965), pp. 401-418 and J. \& H. Schweindinger, "Sociologists of the Chair and the Natural Law Tradition," Insurgent Sociologist 3(Winter 1973), pp. 2-19.

4. Sociology is not alone among the social sciences in taking such an approach to law. For a similar approach and similar problems see the American Anthropologist 67(December 1965). The entire volume is devoted to the anthropological study of law.

5. See R. Miliband, The State in Capitalist Society, London: Weidenfeld \& Nicholson, 1969 for a discussion of a similar flaw in political science. He 
notes that a conception of the state is assumed without any supporting evidence. As with current conceptions of law, the assumed nature of the state becomes less potent when it is subject to empirical research.

6. Critical analyses of crime and the law are best exemplified in the work of some British sociologists. See I. Taylor, P. Walton \& J. Young eds. Critical Criminology, London: Routledge Kegan Paul, 1975. Among American sociologists see R. Quinney, Critique of Legal Order. Boston: Beacon Press, 1974.

\section{REFERENCES}

Akers, Ronald

1975 "The Professional Association and the Legal Regulation of Practice." in Akers, R. \& Hawkins, R. Law and Social Control in Society. New Jersey: Prentice-Hall.

Barak, Gregg

1975 "In Defense of the Rich: The Emergence of the Criminal Defender System." Crime and Social Justice 3(Summer):2-14

Black, Donald

1972 "The Boundaries of Legal Sociology." Yale Law Journal 81(May):1086-1110.

Chambliss, William

1964 "A Sociological Analysis of Vagrancy." Social Problems 12(Summer):67-77.

Currie, Elliot

1971 "The Sociology of Law: The Unasked Questions." Yale Law Journal 81(November):134-147.

Domhoff, William

1969 "Where a .Pluralist Goes Wrong." Berkeley Journal of Sociology 14:35-58.

Ehrlich, Eugen

1922 "The Sociology of . Law." Harvard Law Review 36(December):130-145

1936 The Fundamental Principles of the Sociology of Law. (1913) translated by Eugene Moll Cambridge: Harvard University Press.

Friedman, L. \& Ladinsky, J.

1967 "Social Change and the Law of Industrial Accidents." Columbia Law Review 67(January):50-72.

Geis, Gilbert

1964 "Sociology and Sociological Jurisprudence: Admixture of Law and Lore." Kentucky Law Journal 52(Winter):267-293.
Sociology of Law

Gerth, Hans \& Mills, C.W.

1953 Social Theory and Social Structure. New York: Harcourt Brace \& World.

Gordon, David

1973 "Class and the Economics of Crime," in Weaver, J. ed., Modern Political Economy. Boston: Allyn \& Bacon.

Gouldner, Alvin

1970 The Coming Crisis in Western Sociology. New York: Equinox.

Josephson, $M$.

1934 The Robber Barons. New York: Harcourt Brace.

Katz, Michael

1968

Kolko, G.

The Irony of Early School Reform. Boston: Beacon Press.

1963 The Triumph of Conservatism. New York: Free Press.

1969 The Roots of American Foreign Policy. Boston: Beacon Press.

Kunitz, S.

1974 "Professionalism and Social Control in the Progressive Era: The Case of the Flexner Report." Social Problems 22(Fall):16-28.

Mannheim, Karl

1971 "Conservative Thought." in Wolff, K. ed., From Karl Mannheim. New York: Oxford University Press.

Miliband, Ralph

1969 The State in Capitalist Society. London: Weidenfeld \& Nicholson.

Mills, C.W.

1942 "The Professional Ideology of Social Pathologists," American Journal of Sociology 49(September):165-180.

Parks, Evelyn

1970 "From Constabulary to Police Society," Catalyst 5(Summer):1-37.

Phillips, Derek

1970 "Epistemology and the Sociology of Knowledge," Theory and Society 1:59-88.

Platt, Anthony

1974 "The Triumph of Benevolence: The Origins of the Juvenile Justice System in America," in Quinney R. ed., Crime and Social Justice in America. Boston: Little Brown.

Pound, Roscoe

1912 "Scope and Purpose of Sociological Jurisprudence," Harvard Law Review 25(April):489-516. 
1916 "The Limits of Effective Legal Action," International Journal of Ethics 27:150-167.

1942 Social Control Through Law. New Haven: Yale University Press.

1943 "A Survey of Social Interests," Harvard Law Review 57(October) :39-58.

Quinney, Richard

1974 A Critique of Legal Order. Boston: Beacon Press.

Roby, Pamela

1969 "Politics and the Criminal Law: Revision of the New York State Law on Prostitution," Social Problems 17(Summer):83-109.

Schur, E.

1968 Law and Society. New York: Random House.

Schweindinger, J. \& $\mathrm{H}$.

1973 "Sociologists of the Chair and the Natural Law Tradition," Insurgent Sociologist 3(Winter):2-19.

Selznick, $\mathrm{P}$.

1959 "The Sociology of Law," in Merton et al. eds., Sociology Today. New York: Basic Books.

Serber, D.

1975 "Regulating Reform: The Social Organization of Insurance," Insurgent Sociologist 3(Spring):83-109.

Silver, A.

1967 "The Demand for Order in Civil Society: A Review of Some Themes in the History of Urban Crime, Police and Riots." in Bordua, D. ed., The Police. New York: Wiley.

Smith, D.

1965 "Sociology and the Rise of the Corporate State," Science and Society 29(Fall):401-418.

Snodgrass, J.

1972 "The American Criminological Tradition: Portraits of the Men and .Ideology in a Discipline," Ph.D. Dissertation, University of Pennsylvania.

Stern, P.

1970 "How 381 Super Rich Americans Managed Not to Pay a Cent in Taxes Last Year," in Mermelstein \& Lekachman eds., Economics: Mainstream Readings and Radical Critiques. New York: Random House.

Timascheff, N

1937 "What is Sociology of Law," American Journal of Sociology 43(September):225-235.

Weinstein, J:

1968 The Corporate Ideal in the Liberal State: 1900-1918. Boston: Beacon Press.

\section{BOOK REVIEWS}

Mavis Hiltunen Biesang and John Biesang. Introduction to Sociology. Englewood Cliffs, New Jersey: Prentice-Hall, Inc. 1978.453pp.

This is an introductory text which is based on the premise that the novice sociological student is new to the discipline and therefore has no background in the field. No details have been overlooked by the authors in their efforts to present this material in an easily assimilated manner.

Among the more outstanding and innovative tactics employed are a well-indexed table of contents; the red highlighting of each newly introduced sociological term or phrase (common usage terms and words which often have a sociological interpretation are also emphasized in red); and end-of-the-chapter glossary of new terms and words, and a composite glossary in the appendix; a cross-referenced index to facilitate the collating of related ideas; an annotated bibliography, complied on a chapter-by-chapter basis; a concise, pertinent summary concludes each chapter; and the easy to read format of the columnar printed page.

The text answers the student's questions: What is sociology? What can one do with sociology? How does sociology apply to me? What does sociology hope to accomplish? These questions are answered in a forthright manner. It should whet the introductory student's appetite for further sociological study.

The text is divided into six major sections: The Introduction; Culture and Socialization; Social Structure; Population and the Urban Trend; Social Institutions; and Social Change. Theorists may fault the text on the apparent lack of theoretical emphasis, but in truth, the theory is there, the presentation is simplified, and made palatable and relevant to life.

The material contained in the text is easily understood; not at all condescending. The level and coverage of the material, while intended for the underclassperson, is still pertinent and adaptable for those students who may be further along in their studies. 